\title{
A Resident Initiated Prite Review Course: Trials and Tribulations
}

David W. Metzler, M.S., M.D.

Gunderson Clinic, Ltd., LaCrosse, Wisconsin

Daniel L. Kinsey, M.D.

Gunderson Clinic, Ltd., LaCrosse, Wisconsin

Lesley R. Dickson, M.D.

Gunderson Clinic, Ltd., LaCrosse, Wisconsin

Mark Hyatt, M.D.

Gunderson Clinic, Ltd., LaCrosse, Wisconsin

Follow this and additional works at: https://jdc.jefferson.edu/jeffjpsychiatry

Part of the Psychiatry Commons

Let us know how access to this document benefits you

\section{Recommended Citation}

Metzler, M.S., M.D., David W.; Kinsey, M.D., Daniel L.; Dickson, M.D., Lesley R.; and Hyatt, M.D., Mark (1993)

"A Resident Initiated Prite Review Course: Trials and Tribulations," Jefferson Journal of Psychiatry. Vol. 11

: Iss. 1 , Article 12.

DOI: https://doi.org/10.29046/JJP.011.1.015

Available at: https://jdc.jefferson.edu/jeffjpsychiatry/vol11/iss1/12

This Article is brought to you for free and open access by the Jefferson Digital Commons. The Jefferson Digital Commons is a service of Thomas Jefferson University's Center for Teaching and Learning (CTL). The Commons is a showcase for Jefferson books and journals, peer-reviewed scholarly publications, unique historical collections from the University archives, and teaching tools. The Jefferson Digital Commons allows researchers and interested readers anywhere in the world to learn about and keep up to date with Jefferson scholarship. This article has been accepted for inclusion in Jefferson Journal of Psychiatry by an authorized administrator of the Jefferson Digital Commons. For more information, please contact: JeffersonDigitalCommons@jefferson.edu. 


\title{
Brief Report
}

\section{A Resident Initiated Prite Review Course: Trials and Tribulations}

\author{
David W. Metzler, M.S., M.D. \\ Daniel L. Kinsey, M.D. \\ Lesley R. Dickson, M.D. \\ Mark Hyatt, M.D.
}

The experience of developing a review course to study for the Psychiatry Resident's In-Training Exam (PRITE) is discussed. Residents in our program felt that the review course was useful with respect to the following: studying for the PRITE; future study for National Boards; and learning of new material.

The Psychiatry Resident's In-Training Exam (PRITE) was developed in 1979 as a mechanism to assess the knowledge base of psychiatric residents in a standardized format $(1,2,3)$. The exam was originally designed to simulate the American Board of Psychiatry and Neurology (ABPN) examination, PART I, and has gained widespread acceptance despite questions about its ability to accurately test or reflect the knowledge of the examinee $(1,4,5)$.

Principles derived from a system for self-education of residents published by Taylor and Torrey (6) were applied to a review course developed at this institution to improve the knowledge base of each resident with the goal of increasing performance on the PRITE and, ultimately, ABPN exam Part I. This paper discusses the review course from its conception to final evaluation with views offered from the organizers, the residency director, and the residents taught by this method. It was hypothesized that most participants would feel that the review course was useful in studying for the PRITE exam and that those who had actively participated (i.e., made a handout or gave a lecture) would feel the review course was more useful than those who were passive participants.

\section{Methods}

In early March of 1990, we developed a review course to integrate all aspects of our training, to prepare for the written part of ABPN exam and more immediately to improve PRITE scores. During the weekly residents' meeting, the idea of a PRITE/ ABPN exam review course was presented and strongly endorsed. It was felt to be 
unethical to compare PRITE scores or to ask participants to reveal their future ABPN exam scores. A contemporary basic textbook of psychiatry was divided into sections, reviewed, outlined, and ultimately presented by participating residents in a lecture format.

With this in place, the authors approached the residency education directors for support and were provided with time during the regularly scheduled didactic sessions to give lectures. Residents were required to attend all lectures. Financial support was guaranteed for copying costs and word-processing by the psychiatry department.

Following the review course, resident perspectives were assessed with an anonymous questionnaire entitled "PRITE REVIEW COURSE EVALUATION." The assessment was completed by the residents just prior to the PRITE and one month after the exam.

Results

Twenty-nine residents were eligible to attend the review course. Because of the requirements of internship and other clinical responsibilities the maximum number of residents able to attend any given lecture was 25, and sixteen residents gave lectures. Attendance at lectures varied from 13 to 23 residents despite attendance being "required."

Twenty-one residents returned the first questionnaire and nineteen returned the second. Those who answered the questionnaires attended between $50 \%$ to $75 \%$ of the lectures. There was no statistical difference in Likert scores of individual questions before or after the PRITE was taken.

The residents who filled out the first and second questionnaire agreed that the review course would be, and was, useful in studying for the PRITE exam. They also agreed that the review course would be useful in studying for the ABPN exam Part 1 . There was also high endorsement of the selection of the Synopsis of Psychiatry as an appropriate text for the review course. There was agreement that the review course stimulated study for the exam and that the resident learned something new during the course. There was a suggestion that the review course be done as part of the resident didactics every year. Finally, handouts and lecture notes were used between $25 \%$ to $50 \%$ of the time to study for the PRITE. No significant difference (students t-test for paired observation) in ratings was given by residents who had given a lecture or who had made a handout as compared to those who had not given a lecture or had not made a handout (Data not shown). Each person who answered the questionnaire also ranked the various teaching methods used in the review course.

Discussion

It was evident that the review course was well-received by a majority of the residents. Most felt that it was helpful, provided new information, and stimulated study for the PRITE. There was overwhelming agreement that the Synopsis of 
Psychiatry was appropriate as a text. Handouts plus lectures as well as the use of old PRITE questions were felt to be the best methods of teaching.

Although there was initial enthusiasm for the project, not all residents were willing to participate in outlining a topic or giving a lecture. Only 4 of 17 people completed their outlines by the original deadline and despite pressure to complete their outline, 3 people waited until the week of their lecture. This situation exemplifies one of the major drawbacks to this method of course organization. Because of financial constraints within the psychiatry department, monetary support and wordprocessing services were withdrawn in the middle of the project. This resulted in the organizers doing the majority of clerical work which included typing of the outlines, copying, stapling, and handing out the materials.

The training director observed this course with much interest and support for the initiative of the residents, the effective use of didactic time and the desire to improve PRITE performance. Additionally, residents found that one of the most effective ways to learn a subject was to prepare a lecture or handout, demonstrating the concept of self-learning. Additional learning experiences, particularly for the organizers, included the difficulties encountered in teaching, such as problems in motivating participants, technical difficulties, financial constraints and the deflating experience of poor attendance of a bored audience.

The final question to be asked is: Should the review course be done again, and, if so, how should it be done? Most of the residents felt that the course was worthwhile. We believe that the advantages outweigh the disadvantages if certain conditions are present:

1. Financial commitment (budgeted money) from the department to cover typing and copying costs. Residents might contribute a nominal fee (outside review courses can cost $\$ 750)$.

2. A core of seriously committed residents $(\geq 5)$ to work out the problems that will arise.

3. Use of a readable general text (In theory, this format could be used to go through other books).

4. Guidelines for lectures that would encourage creative methods of teaching. Consider awards for the best lecture and handouts.

5. Mandatory attendance.

6. Pre- and Post-course examination to assess increased knowledge base and identify weaknesses.

7. Use of old PRITE and ABPN exam Part I questions as well as case scenarios to stimulate thinking (Videotaped case scenarios may also be helpful).

8. Supplemental recent articles in all areas to provide up-to-date information since texts are 1-2 years behind in information.

9. Use of faculty and advisors. Also have faculty sit in on lectures to offer their expertise. In fact, a case scenario could be used by faculty in a problem-based learning format to further explore the body of knowledge presented. 


\section{REFERENCES}

1. Strauss GD, Yager J, and Strauss GE: Assessing Assessment: The content and quality of the Psychiatry In-Training Examination. Am J Psychiatry 1982; 139(1):85-88

2. Kay J (editor): Handbook of Psychiatry Residency Training. American Psychiatric Association, Washington, D.C., 1991. Chapter 4 by Lomax JW and Reider RO. pp 83-106

3. Nadelson DD and Robinowitz CB (editors): Training Psychiatrists for the '90s: Issues and Recommendations. American Psychiatric Press. Chapter 21 by Shader RI. pp 153-155

4. Strauss GD, Yager J, and Liston EH: A comparison of national and in-house examinations of psychiatric knowledge. Am J Psychiatry 1984; 141:882-884

5. Hanson CD, Privitera CR, Mazur E: Standardized assessment of psychiatric residents. Journal of Psychiatric Education 1986; 10(4):215-227

6. Taylor RL and Torrey EF: The self-education of psychiatric residents. Am J Psychiatry 1972; 128(9):1116-1121 